\title{
Evaluation of different methods to obtain primary mammary epithelial cell cultures from canine spontaneous mammary gland tumors
}

\author{
Luciana B Gentile, Márcia K Nagamine ${ }^{1}$, Isis P Jesus ${ }^{1}$, Fábio T Toyota² ${ }^{2}$ Adriana T Nishiya ${ }^{3}$, Tatiane M Giovani ${ }^{4}$, \\ Daniel S Sanches ${ }^{1}$, Heidge Fukumasu ${ }^{4}$, Maria Lúcia Z Dagli ${ }^{{ }^{*}}$
}

From São Paulo Advanced School of Comparative Oncology

Águas de São Pedro, Brazil. 30 September - 6 October 2012

\section{Background}

Mammary gland neoplasms are the most prevalent tumors in dogs, and their treatment is still challenging. A crucial problem in the handling of this type of neoplasm is to obtain primary mammary epithelial cell cultures from the original tumors. The aim of this study was to determine the best conditions to culture primary mammary epithelial cells from several histological types of canine breast tumors.

\section{Materials and methods}

Several culturing conditions have been tested including enzymes such as collagenases types III and IV, trypsin and hyaluronidase, differential centrifugation and trypsinization. Four tumor samples were processed to obtain organoids, stromal and epithelial cells. The histological tumor types studied were mixed carcinoma and simple adenoma. The cells were phenotypically characterized according to an immunocytochemical panel, including cytokeratins, alpha smooth muscle actin and vimentin.

\section{Results}

Results have shown that the best method of obtaining primary epithelial cell lines comprises the use of collagenase type I, hyaloronidase and trypsin followed by serial differential trypsinization.

\section{Conclusions}

Standardization of such methodological tools in the canine model for the study of cancer will allow a more detailed analysis of the action of new antineoplastic agents, which could be applied to animals and, eventually, to humans.

\section{Financial support \\ FAPESP and CNPq.}

\begin{abstract}
Author details
'Laboratory of Comparative and Experimental Oncology, Department of Pathology, School of Veterinary Medicine and Animal Sciences, University of São Paulo (USP), São Paulo, Brazil. Veterinary Hospital Cães e Gatos, Osasco, São Paulo, Brazil. '3niversity Anhembi Morumbi, São Paulo, Brazil. ${ }^{4}$ Department of Pathology, School of Veterinary Medicine and Animal Sciences, University of São Paulo (USP), São Paulo, Brazil.
\end{abstract}

Published: 4 April 2013

doi:10.1186/1753-6561-7-S2-P41

Cite this article as: Gentile et al:: Evaluation of different methods to obtain primary mammary epithelial cell cultures from canine

spontaneous mammary gland tumors. BMC Proceedings 2013 7(Suppl 2): P41.

\footnotetext{
* Correspondence: mlzdagli@usp.br

'Laboratory of Comparative and Experimental Oncology, Department of

Pathology, School of Veterinary Medicine and Animal Sciences, University of

São Paulo (USP), São Paulo, Brazil

Full list of author information is available at the end of the article
}

(c) 2013 Gentile et al; licensee BioMed Central Ltd. This is an Open Access article distributed under the terms of the Creative Commons 